\begin{tabular}{|l|l|l||}
\hline \multicolumn{2}{|c|}{ PublisherInfo } \\
\hline \hline PublisherName & $:$ & BioMed Central \\
\hline \hline PublisherLocation & $:$ & London \\
\hline \hline PublisherImprintName & $:$ & BioMed Central \\
\hline \hline
\end{tabular}

\title{
Circadian regulation of reward
}

\begin{tabular}{|l|c|l||}
\hline \multicolumn{2}{|c|}{ ArticleInfo } \\
\hline \hline ArticleID & $:$ & 5093 \\
\hline \hline ArticleDOI & $:$ & $10.1186 /$ gb-spotlight-20050614-01 \\
\hline \hline ArticleCitationID & $:$ & gb-spotlight-20050614-01 \\
\hline \hline ArticleSequenceNumber & $:$ & 69 \\
\hline \hline ArticleCategory & $:$ & Research news \\
\hline ArticleFirstPage & $:$ & 1 \\
\hline \hline ArticleLastPage & $:$ & 3 \\
\hline \hline & & RegistrationDate : 2005-6-14 \\
\hline ArticleHistory & $:$ & OnlineDate \\
\hline \hline ArticleCopyright & $:$ & BioMed Central Ltd2005-6-14 \\
\hline \hline ArticleGrants & $:$ & \\
\hline \hline ArticleContext & $:$ & 130596611 \\
\hline \hline
\end{tabular}




\section{Melissa Lee Phillips}

Email: mlp@nasw.org

In mice, the circadian gene Clock is involved in regulating the brain's dopaminergic reward pathway, researchers report in this week's PNAS. They found that animals with no functional CLOCK protein were more susceptible to the behavioral effects of cocaine and had elevated dopamine transmission in the reward pathway for drugs, food, and sex.

A link between circadian rhythms and behavioral response to cocaine has been suggested byprevious work, lead author Colleen McClung, of the University of Texas Southwestern Medical Center, told The Scientist. "But there wasn't a whole lot showing that the individual genes involved in circadian rhythms are also involved in reward pathways," McClung said.

She and her colleagues examined the effect of cocaine in mice that did not make the CLOCK protein, which is a transcription factor with a central role in the body's suprachiasmatic nucleus circadian clock.

The investigators found that Clock mutants were abnormally physically active even without cocaine. The mutants also showed greater cocaine sensitization than wild-type controls, as measured by increasing movement levels with repeated cocaine doses.

The mice without Clock also spent much more time than did wild-type mice in the parts of their cages where they could get cocaine, which hints that the mutants found cocaine more rewarding, McClung said.

The researchers next examined the Clock mutants' neural activity in the ventral tegmental area (VTA) dopamine system. This system mediates the rewards felt from drugs like cocaine, as well as from natural rewards like food and sex - "anything that causes you to have a good feeling, basically," McClung said.

They found CLOCK protein expressed in all of the VTA's dopaminergic neurons, which they identified by the presence of tyrosine hydroxylase $(\mathrm{TH})$, the rate-limiting enzyme in dopamine synthesis.

The Clock mutant mice had two to three times as much TH-and two to three times as much phosphorylated TH-in the VTA as did wild-type mice. "Overall increases in TH and in phosphorylation of TH are involved in the production of dopamine," McClung said. "The cells, presumably, are making more dopamine and so they're releasing more dopamine."

VTA dopaminergic neurons were also more excitable in Clock mutants. This increase in dopaminergic neuron firing is similar to what is seen in other animal models of increased sensitivity to cocaine, the researchers said.

Finally, using a DNA microarray of VTA tissue, the authors found several genes differentially regulated in the mutants that are known to be involved in dopamine transmission, including several glutamate receptors, a GABA receptor, and an ion channel.

It's nice that the researchers "looked for the neurochemical and anatomical substrates for the effect of the Clock gene mutation," David Weaver of the University of Massachusetts Medical School, who was 
not involved in the study, told The Scientist. This is the first study to connect a circadian clock mutation to changes in gene expression in the dopaminergic reward pathway, Weaver said.

McClung and her colleagues suspect that regulation of these genes, in addition to regulation of TH, could contribute to elevated dopamine activity in the mutant mice. But they don't yet know if these gene expression changes are a direct result of CLOCK transcriptional regulation, McClung said.

McClung's results hint at how "the circadian system controls reward and motivation generally," according to Michael Lehman of the University of Cincinnati School of Medicine, who was not involved in the study. It makes sense if animals respond to rewarding stimuli in the environment differently at different times of the day, Lehman said.

It's becoming clear that circadian genes influence many phenotypes "beyond what...we normally thought of as being under circadian regulation," Lehman said. "This is an extension of that."

\section{References}

1. C. McClung et al., "Regulation of dopaminergic transmission and cocaine reward by the Clock gene, " PNAS, 2005., [http://www.pnas.org]

2. C. Abarca et al., "Cocaine sensitization and reward are under the influence of circadian genes and rhythm," PNAS, 99:9026-30, June 25, 2002., [http://PMID:12084940]

3. Colleen McClung, [http://www3.utsouthwestern.edu/molpsych/Students_02.htm\#McClung]

4. David Weaver, [http://www.umassmed.edu/neuroscience/faculty/weaver.cfm]

5. Michael Lehman, [http://www.med.uc.edu/cellbio/CVs/lehman.shtm] 